\title{
Determinants of Regional Tax Revenue in Central Java Province
}

\author{
Shanty Oktavilia ${ }^{1}$, Yozi Aulia Rahman ${ }^{2}$, Fafurida $^{3}$, Salman Arif $^{4}$ \\ \{yoziaulia@mail.unnes.ac.id²\} \\ Universitas Negeri Semarang, Indonesia ${ }^{1,2,3,4}$
}

\begin{abstract}
Regional autonomy motivates regional government for being independent in managing and exploring fund local development. Tax is one of the local revenue sources that plays an important role. This study aims to analyze factors such as Gross Regional Domestic Products (GRDP), Consumer Price Index (CPI), total population and number of hotels to local revenue of districts or cities in Central Java from 2014 to 2018. The dependent variables employed are GDP, CPI, total population and hotel. This study implements a multiple regression analysis with an OLS method and panel data. The data panel used is a fixed-effect model. The research shows that GRDP, total population and number of hotels impact the regional revenue positively and significantly. However, CPI influences local revenue negatively and significantly.
\end{abstract}

Keywords: Regional Tax, GRDP, CPI, Total Population, Number of Hotel

\section{Introduction}

Indonesia implemented a regional autonomy after an MPR (The People's Consultative Assembly) Decree Number XV/MPR/1998 about the implementation of regional autonomy, management, division and equitable utilization of national resources and balance between central and regional finance within The Indonesia Republic was issued. Since the new order government's fall in 1998, Indonesia has changed from the most authoritarian country to the most democratic and decentralized country [1]. The political situation changes have pushed the government to decrease expenditure and change political ideology by bringing power and responsibility closer to the people [2].

Officially, Indonesia started a regional autonomy on the 1st of January 2001. According to Smith [3], decentralized politics in Indonesia is the biggest project of decentralized politics. This phenomenon is due to the transfer of 2 million public civil servants from the central government to the regional one such as districts or cities. Kis-Katos and Sjahrir [4] argued that Indonesia has simultaneously carried out a decentralization in three dimensions: politics, fiscal, and administrative. Indonesia implemented politics and administrative decentralization by giving full authority to the regional governments in managing their territories and direct general election for local governments and DPRD (Regional House of Representative).

Further, regional governments can manage their finance from regional fund sources and intergovernmental transfers. Even though Indonesia has implemented autonomy for 20 years, but many weaknesses still come up. Badrudin and Siregar [5] viewed that regional autonomy goals have not been successfully increased the society's welfare because of many factors such as the regional government inability in managing the regional finance and budget fraud. 
Central Java Province is one of the large provinces in Indonesia. After the implementation of regional autonomy, there is an increase in regional revenue and expenditure. Haniz and Sasana [6] wrote that the bigger the authority, given from the central government to the regional government, the more significant the regional revenue role in the regional structural finance. Hence, regional revenue becomes the primary finance source in regional autonomy. Table 1 illustrates the Development of Regional Revenue and Expenditure of Central Java Province from 2014 to 2018.

Table 1. The Development of Regional Revenue and Regional Expenditure of Central Java Province from 2014 to 2018

\begin{tabular}{cccc}
\hline Year & Regional Revenue & Regional Expenditure & $\begin{array}{c}\text { Contribution } \\
\text { Percentage }\end{array}$ \\
\hline 2014 & $9,916,358,231,432$ & $15,086,065,034,422$ & $66 \%$ \\
\hline 2015 & $10,904,825,812,504$ & $17,820,760,495,342$ & $61 \%$ \\
\hline 2016 & $11,541,029,720,310$ & $19,354,374,825,983$ & $60 \%$ \\
\hline 2017 & $12,547,513,389,400$ & $22,884,713,018,754$ & $55 \%$ \\
\hline 2018 & $12,994,933,643,000$ & $24,478,632,557,339$ & $53 \%$ \\
\hline \multicolumn{4}{l}{ Source: DJPK (Directorate General of Fiscal Balance) Ministry of Finance (processed) [7]. }
\end{tabular}

Table 1 shows that regional revenue and expenditure in Central Java Province increase from 2014-2018. However, the contribution percentage of regional revenue to the regional expenditure dropped at the same time. In 2014, the regional revenue contribution was $66 \%$. In 2018, the regional revenue contribution was lowered to 53\%. According to Ambariani et al. [8], the decline of regional revenue contribution indicates that the regional revenue resource management was not optimal.

The regional revenue can be from regional tax, retribution and other legitimate wealth. To increase the regional revenue, and prevent the declining regional revenue, maximizing the regional tax revenue is necessarily carried out. The regional tax becomes one of the potential and significant regional revenue resources. The regional tax and retribution have essential roles in financing the regional government development.

Marian and Toth [9] stated that regional tax is an important revenue source for districts and cities to provide more public services. Moreover, the tax also accelerates economic growth in a provincial area. The increasing contribution and tax role in economic growth and development oblige the government to increase the tax revenue. Besides, the number of tax contributions can benchmark the government's success in managing and exploring the potency and existed sources in a region to finance the regional expenditure. Table 2 shows the average of regional tax contribution percentage to the regional revenue in Central Java from 2014 to 2018

Table 2. The Average Percentage of Regional Tax Contribution to Regional Revenue in Central Java Province from 2014 to 2018

\begin{tabular}{lccc}
\hline \multicolumn{1}{c}{ Districts/Cities } & $\begin{array}{c}\text { Regional } \\
\text { Revenue Average }\end{array}$ & $\begin{array}{c}\text { Regional Tax } \\
\text { Revenue Average }\end{array}$ & $\begin{array}{c}\text { Contribution } \\
\text { Percentage Average }\end{array}$ \\
\hline Banjarnegara District & $219,348,362,395$ & $44,014,346,733$ & $20.07 \%$ \\
\hline Banyumas District & $549,465,193,286$ & $159,677,295,515$ & $29.06 \%$ \\
\hline Batang District & $203,934,429,545$ & $57,462,934,425$ & $28.18 \%$ \\
\hline Blora District & $191,125,886,166$ & $40,235,018,000$ & $21.05 \%$ \\
\hline Boyolali District & $302,286,455,446$ & $90,605,448,759$ & $29.97 \%$ \\
\hline
\end{tabular}




\begin{tabular}{lccc}
\hline Brebes District & $355,889,826,573$ & $72,906,692,137$ & $20.49 \%$ \\
\hline Cilacap District & $477,627,359,241$ & $144,292,561,374$ & $30.21 \%$ \\
\hline Demak District & $282,809,843,000$ & $100,642,520,812$ & $35.59 \%$ \\
\hline Grobogan District & $312,684,903,321$ & $60,690,435,227$ & $19.41 \%$ \\
\hline Jepara District & $303,859,039,433$ & $79,751,782,098$ & $26.25 \%$ \\
\hline Karanganyar District & $306,070,248,688$ & $127,637,990,892$ & $41.70 \%$ \\
\hline Kebumen District & $314,782,206,788$ & $67,484,288,290$ & $21.44 \%$ \\
\hline Kendal District & $292,160,749,661$ & $89,072,635,402$ & $30.49 \%$ \\
\hline Klaten District & $272,069,035,582$ & $85,492,332,976$ & $31.42 \%$ \\
\hline Kudus District & $294,398,478,564$ & $88,896,726,472$ & $30.20 \%$ \\
\hline Magelang District & $304,230,755,716$ & $100,449,006,518$ & $33.02 \%$ \\
\hline Pati District & $347,620,560,498$ & $67,701,183,688$ & $19.48 \%$ \\
\hline Pekalongan District & $286,770,202,464$ & $45,148,394,909$ & $15.74 \%$ \\
\hline Pemalang District & $289,922,772,157$ & $52,766,556,137$ & $18.20 \%$ \\
\hline Purbalingga District & $261,714,085,821$ & $47,377,621,851$ & $18.05 \%$ \\
\hline Purworejo District & $255,074,012,143$ & $47,377,621,851$ & $18.57 \%$ \\
\hline Rembang District & $237,963,554,433$ & $57,908,752,239$ & $24.34 \%$ \\
\hline Semarang District & $329,298,899,739$ & $121,472,172,596$ & $36.89 \%$ \\
\hline Sragen District & $311,630,658,388$ & $68,834,066,118$ & $22.09 \%$ \\
\hline Sukoharjo District & $367,995,644,866$ & $178,587,862,432$ & $48.53 \%$ \\
\hline Tegal District & $324,316,520,729$ & $78,097,812,739$ & $24.08 \%$ \\
\hline Temanggung District & $243,007,983,090$ & $34,464,012,036$ & $14.18 \%$ \\
\hline Wonogiri District & $242,967,076,285$ & $34,464,012,036$ & $16.25 \%$ \\
\hline Wonosobo District & $202,531,742,743$ & $27,951,515,047$ & $16.17 \%$ \\
\hline Magelang City & $211,071,205,743$ & $27,951,515,047$ & $13.24 \%$ \\
\hline Pekalongan City & $169,188,352,220$ & $54,872,083,765$ & $32.43 \%$ \\
\hline Salatiga City & $193,139,254,087$ & $44,986,779,805$ & $23.29 \%$ \\
\hline Semarang City & $1,488,951,077,788$ & $1,035,507,756,532$ & $69.55 \%$ \\
\hline Surakarta City & $437,849,005,125$ & $264,046,064,603$ & $60.31 \%$ \\
\hline Tegal City & $276,546,713,806$ & $60,320,055,079$ & $21.81 \%$ \\
\hline Central Java & $\mathbf{1 3 , 5 8 1 , 3 0 4 , 3 3 9 , 1 4 9}$ & $\mathbf{4 , 8 5 8 , 3 7 7 , 0 9 8 , 1 6 6}$ & $\mathbf{3 5 . 7 7 \%}$ \\
\hline
\end{tabular}

Source: DJPK (Directorate General of Fiscal Balance) Ministry of Finance (processed) [7].

In five years (from 2014-2018) the average regional tax contribution to regional revenue reached $35.77 \%$. Based on contribution criteria developed by Research and Development Team of the Department of Internal Affairs-Faculty of Social and Political Sciences, Gajah Mada University, a region with a contribution of $30.1 \%$ is categorized as a region with good contribution and a region with very good if the contribution is more than $50 \%$. Further, an area with a contribution of less than $30 \%$ can be categorized as moderate; low if the contribution is $10.1 \%$ to $20 \%$; and very low if its contribution is $0 \%$ to $10 \%$. Table 2 illustrates 12 of 35 districts or cities in Central Java have a good or outstanding contribution. Semarang is the capital city of Central Java has the average regional tax contribution of $69.55 \%$ to regional revenue.

On the other hand, 23 districts/cities are categorized as moderate or poor. The cities with the lowest contribution are Magelang city with $13.24 \%$ and Temanggung with $14.18 \%$. Generally, based on the data, there is a tax gap between regions. Further, many cities or districts have low tax contribution to the regional tax. 
Nastiti [10] proposed the factors that impact the regional tax are GNP, inflation and total population. The research finding shows that GNP and total population influence the regional tax positively and significantly. Meanwhile, total population impacts negatively and considerably to the regional tax. Velaj and Prendi [11] researched the factors that affect the Albania's tax revenue: GDP, inflation, unemployment, and import. Their finding shows that GDP, inflation and import give positive impact to the tax. Solot [12] also found that GRDP, number of hotels, CPI, etc. influence the regional tax. Number of hotel influence tax revenue positively through the tax levied on a hotel. Maličká et al. [13], viewed that inflation and population impact regional tax revenue in the European Union states. Terefe \& Teera [14] wrote that GNP per capita and inflation affect East Africa countries' tax revenue. Velaj and Prendi [11] noted that GNP and inflation can impact the tax revenue in Albania.

This study aims to identify the factors that influence regional tax revenue in Central Java Province, Indonesia. Independent variables in this study include gross regional domestic product, Consumer Price Index, Total Population, and Number of hotels. This paper is structured as follows; section 2 presents the research methods, section 3 shows and review about results and discussion and section 4 presents conclusion.

\section{Research Methods}

This study used secondary data from government organization such as Directorate General of Fiscal Balance (DJPK) [7] and Central Bureau of Statistics (BPS) [15][16]. This study also employed time-series data and cross-section data. Time series data used were from 2014 to 2028, and cross-section data were from 35 districts or cities in Central Java province. The following is the model regression equation of panel data with the independent variables written as follow tax revenue, gross regional domestic product (GRDP), Consumer Price Index (CPI), Total Population (POP) and Number of hotel (HO):

$$
\text { TAXREVit }=\beta 0+\beta 1 \text { GRDPit }+\beta 2 \text { INFit }+\beta 3 \text { POPit }+\beta 4 \mathrm{HOit}+\varepsilon
$$

\section{Results and Discussion}

The preliminary test done is to determine the best model used to estimate the model. The test result indicates the best model for the next estimation is fix effect model. The following is the estimation result by implementing the fix effect model:

Table 3. The Regression Result of Fixed Effect Model

\begin{tabular}{ccccc}
\hline Variable & Coefficient & Error Standard & t-statistics & Prob. \\
\hline C & -672065.2 & 232506.5 & -2.890522 & 0.0045 \\
\hline GRDP & 0.014633 & 0.001261 & 11.60746 & 0.0000 \\
\hline CPI & -2605.433 & 448.0651 & -5.814852 & 0.0000 \\
\hline$P O P$ & 0.745657 & 0.286477 & 2.602852 & 0.0103 \\
\hline$H O$ & 524.0144 & 143.7920 & 3.544253 & 0.0004 \\
\hline & Source: Processed data. ${ }^{*}$ level of significance $(\alpha)=5 \%$. &
\end{tabular}


The estimation test yields the R-squared value of 0.990648 . The score means that GRDP, CPI, total population and hotel can explain the variable of tax revenue which is $99.06 \%$. Simultaneously, other variables that are not under the study also contribute to influencing the tax revenue, $0.94 \%$. The independent variables affect the dependent variable with a significant value of 0.05 , and $f$ count is greater than $f$ table $(376.3296>2.43)$. Thus, it can be inferred that GRDP, CPI, total population and hotel influence regional tax revenue significantly and simultaneously.

The coefficient value of GRDP variable is 0.014333 . If there is a rise of 1 rupiah, it will raise the tax revenue as many as 0.14633 rupiahs. The GRDP value can describe the economic growth condition in an area. That result supports the researches carried out by Terefe \& Teera [14] and Velaj \& Prendi [11]. The GRDP value, which is increasing and increasing, reflects society's income, rising too. In other words, society's living standard, the ability to meet daily life and ability to pay increase.

Consumer Price Index (CPI) influence regional income negatively and significantly. The coefficient of CPI variable is -2605.433. It means that one increasing point of CPI will decline the tax revenue of 2605.433 rupiahs. The finding supports Gobachew [17], Terefe \& Teera [14] and Velaj \& Prendi [11], who argued that the increase of daily life will drop purchasing power and finally it will lead to committing tax evasion. High inflation occurs in a long time and will affect society's awareness of paying taxes [18].

Lumy et al. [19] explained that an increase in the price of goods and services can positively and negatively impact regional tax avenue. The duration of the increasing price occurrence also contributes to the tax revenue. A short run increasing price will enhance economic growth. However, if the rising cost lasts for a long time, it will weaken economic growth.

On the contrary, some other researches do not support this study. Wildan [20] and Sania (2018) stated that CPI does not affect the tax revenue as tax is obliged. The government has issued rules about taxes so that every citizen registered as a taxpayer must pay the insured tax even though the price of goods and service increase.

Total population affect the regional tax income positively and significantly. The positive coefficient value of 0.745657 indicates that the entire population positively influences regional tax revenue. An increase in the population of one person will raise the tax revenue of 0.745657 rupiahs. The increasing total population will enhance the rising number of taxpayers. However, the negative effect will also appear if the quality of human resources does not improve.

Hansen theory (secular stagnation) explains that a high total population and increasing total production will push society's income. The raising society's productivity will affect their income and ability to pay tax. Thus, the raising of the total population does not always trigger economics problems. Arianto [21] viewed that increasing population in each year will raise the tax payer's number. However, Maličká [13] proposed that in the long run, the raising of tax revenue will occur if the number of productive age is greater than the non-productive.

Number of hotel variable also influences the regional tax income positively and significantly with the coefficient value of 524.0144. If there is a one hotel unit raise, it will raise the regional income tax revenue as many as 524 rupiahs. The hotel's number in an area reflects whether other people living outside the area demand the site. The number of a hotel that is always raising indicates that the sources exist in the area can be managed optimally to attract other society of other regions. Solot [12] stated that the hotel's number significantly influences the tax revenue through the tax levied on hotel and regional revenue. One of the factors that enhances the raise of a hotel in an area is the tourism sector. Tourists' visits to the tourism object motivate new hotels built to meet the market demand. Regional government levies tax on each amenity provided. It is as the contribution of business people to the government. Therefore, the 
study's implication argued by Castro and Camarillo [22] is that the government should have a relevant effort to increase the tax revenue in a developing country that is structural reformation implementation.

\section{Conclusion}

Based on the discussion on the factors that affect the regional tax revenue in districts or cities in Central Java Province, it can be inferred that GRDP influence regional tax revenue positively and significantly. In other words, the raise of GRDP will raise regional tax revenue. To maximize the PDRB, the government should stimulate the existed economics potency. CPI influence the regional tax revenue negatively and significantly in districts/cities in Central Java. It means that the increase of CPI can decline the regional tax revenue in districts or cities in Central Java. To decrease and prevent the negative effect of CPI triggers inflation, the government should control the availability of goods and services; and stabilize the price of basic needs.

Total population affects the regional revenue positively and significantly. It indicates that high total population will increase the regional tax revenue. Next, the increase will occur if the population productivity grows. It will then lead the society to have higher income and finally increase the ability to pay tax. The role of government in providing job vacancies and work training is necessary to encourage society's productivity. The number of hotels also influences positively and significantly to the regional tax revenue. The government can maximize this revenue by supervising and listing all the hotels, include the new ones in an area.

\section{References}

[1] S. Butt, "Regional Autonomy and Legal Disorder: The Proliferation of Local Laws in Indonesia," Sing. J. Leg. Stud, vol. 1, 2010.

[2] S. Kristiansen and P. Santoso, "Surviving decentralisation?: Impacts of regional autonomy on health service provision in Indonesia," Health Policy (New. York)., vol. 77, no. 3, pp. 247-259, 2006.

[3] B. Smith, "The origins of regional autonomy in Indonesia: Experts and the marketing of political interests," J. East Asian Stud., pp. 211-234, 2008.

[4] K. Kis-Katos and B. S. Sjahrir, "The impact of fiscal and political decentralization on local public investment in Indonesia," J. Comp. Econ., vol. 45, no. 2, pp. 344-365, 2017.

[5] R. Badrudin and B. Siregar, "The evaluation of the implementation of regional autonomy in Indonesia," Econ. J. Emergin Mark., vol. 7, no. 1, pp. 1-11, 2015.

[6] N. F. Haniz and H. Sasana, "Analisis Faktor-faktor yang Mempengaruhi Penerimaan Pajak Daerah Kota Tegal." Fakultas Ekonomika dan Bisnis, 2013.

[7] Direktorat Jenderal Perimbangan Keuangan, APBD, Realisasi APBD, dan Neraca. Jakarta: DJPK Kementerian Keuangan Republik Indonesia, 2019.

[8] N. L. P. N. Ambariani, I. K. A. Purnawan, and K. S. Wibawa, "Aplikasi Pengenalan Jenis KupuKupu Langka Berbasis Augmented Reality,” J. Ilm. Merpati (Menara Penelit. Akad. Teknol. Informasi), p. 12, 2017.

[9] G. Marián and T. Peter, "Significance of Local Taxes in Income Structure of Slovak Municipalities," Mediterr. J. Soc. Sci., vol. 6, no. 3, p. 544, 2015.

[10] C. R. Nastiti, "Analisis Faktor-Faktor Yang Mempengaruhi Pajak Daerah,” J. Ilm. Mhs. FEB, vol. 4, no. 1, 2015.

[11] E. Velaj and L. Prendi, "Tax revenue-The determinant factors-The case of Albania," Eur. Sci. J., 2014. 
[12] F. T. Solot, "Pengaruh Jumlah Hotel Terhadap Pendapatan Asli Daerah (Pad) Melalui Pajak Hotel Sebagai Intervening (Studi Kasus Di Kota Yogyakarta Tahun 2013-2016)," J. Ekobis Dewantara, vol. 1, no. 2, pp. 70-81, 2018.

[13] L. Maličká, M. Harčariková, and V. Gazda, "Determinants of local tax revenues in EU countries," Eur. J. Econ. Financ. Adm. Sci., vol. 52, pp. 120-126, 2012.

[14] K. D. Terefe and J. Teera, "Determinants of tax revenue in East African countries: An application of multivariate panel data cointegration analysis," J. Econ. Int. Financ., vol. 10, no. 11, pp. 134 155,2018

[15] Badan Pusat Statistik, Produk Domestik Regional Bruto Provinsi Jawa Tengah Menurut Lapangan Usaha Tahun 2014-2018. Jawa Tengah: Badan Pusat Statistik, 2019.

[16] Badan Pusat Statistik, Pedoman Survei Statistik Harga Konsumen. Jakarta: Badan Pusat Statistik, 2009.

[17] N. Gobachew, "Determinants of Tax Revenue in Ethiopia." 2017.

[18] E. D. N. Komala, "Pengaruh Perilaku Pemimpin dan Lingkungan Kerja terhadap Kepuasan Kerja (Studi pada Karyawan STIE Putra Bangsa Kebumen)," VOLATILITAS, vol. 1, no. 6, 2019.

[19] D. G. Lumy, P. Kindangen, and D. S. M. Engka, "Analisis Faktor-Faktor Yang Mempengaruhi Penerimaan Pajak Daerah Pada Pemerintah Provinsi Sulawesi Utara," J. Pembang. Ekon. DAN Keuang. Drh., vol. 19, no. 2, pp. 1-16, 2021.

[20] A. Wildan, "Pengaruh Tamu Hotel, IHK dan Tenaga Kerja Hotel Terhadap Penerimaan Pajak Hotel Kabupaten Semarang," Econ. Dev. Anal. J., vol. 7, no. 1, pp. 39-44, 2018.

[21] W. Y. Arianto, "Pengaruh Beban Pajak Penghasilan Dan Kebijakan Dividen Terhadap Kebijakan Leverage Pada Perusahaan Manufaktur Yang Terdaftar Di Bursa Efek Indonesia Tahun 20122016," 2018

[22] G. Á. Castro and D. B. R. Camarillo, "Determinants of tax revenue in OECD countries over the period 2001-2011," Contaduría y Adm., vol. 59, no. 3, pp. 35-59, 2014. 